\title{
Pendampingan kelompok guru SD di kecamatan Genuk tentang pemahaman metodologi penelitian pendidikan (action research \& experiment) dan penyusunan artikel jurnal
}

\author{
${ }^{1}$ Nuhyal Ulia ${ }^{*}$ Rida Fironika KD, ${ }^{3}$ Yulina Ismiyanti, ${ }^{4}$ Sari Yustiana, \\ ${ }^{5}$ Jupriyanto, ${ }^{6}$ Andarini Permata Cahyaningtyas \\ $1,2,3,4,5,6$ \\ Universitas Islam Sultan Agung (PGSD, FKIP, UNISSULA), \\ Semarang, Indonesia \\ *Corresponding Author \\ nuhyalulia@unissula.ac.id
}

\begin{abstract}
Abstrak
Kenaikan pangkat dan golongan bagi Guru PNS menjadi hal yang penting, namun yang harus dilakukan diantaranya adanya publikasi kegiatan ilmiah sebagaimana Permen PAN dan Reformasi Birokrasi Nomor 16 Tahun 2009. Bentuk publikasi ilmiah dapat berasal dari penelitian action research dan eksperimen. Pengetahuan Guru SD tentang metodologi penelitian action research dan penelitian eksperimen serta penulisan artikel ilmiah pada jurnal yang masih minim menjadi masalah tersendiri bagi guru tersebut. Pengabdian Masyarakat tersebut bekerja sama dengan kelompok guru di kecamatan Genuk kota Semarang Provinsi Jawa Tengah. Pelaksanaan pengabdian masayarakat, dalam bentuk kegiatan pelatihan, workshop, pendampingan penelitian dan menyusun artikel jurnal. Artikel jurnal dari peserta pengabdian yang sudah memenuhi syarat maka akan berkesempatan untuk dipublish pada jurnal pendidikan dasar PGSD UNISSULA. Pelaksanaan pengabdian dilakukan dengan mitra kelompok guru di kecamatan Genuk, namun pada pelaksanaannya tim pengabdian disarankan langsung terjun ke SD di lingkungan UPTD Genuk, sehingga tim pengabdian memilih 2 SD di lingkungan UPTD Genuk yaitu SDN Gebangsari 03 dan SDN Genuksari 02. Peserta terdiri dari guru-guru di SD tersebut sejumlah 50 peserta. Tingkat antusiasme dalam mengikuti kegiatan pengabdian sangatlah tinggi. Adapun materi yang diberikan saat pelatihan meliputi Penelitian Tindakan Kelas (PTK), penelitian eksperimen, teknik submit artikel jurnal melalui OJS. Kegiatan pengabdian berlangsung selama 2 bulan di tiap SD yakni pelaksanaan di SDN Gebangsari 03 pada bulan Juli sampai Agustus 2018 sedangkan di SDN Genuksari 02 dilaksanakan dalam Bulan September sampai Oktober 2018 dimulai dari observasi ke lokasi pengabdian, identifikasi masalah sampai dengan pelatihan dan pendampingan pembuatan penelitian dan artikel jurnal. Dari kegiatan pengabdian yang sudah dilaksanakan ada harapan dari pihak mitra untuk menindaklanjuti kegiatan ini dengan kegiatan pelatihan PTS atau penelitian tindakan sekolah bagi kalangan kepala sekolah.
\end{abstract}

Kata kunci: Action research, artikel jurnal, kelompok guru SD, pendampingan metodologi penelitian. 
The promotion and class for PNS teachers is important, but what must be done is the publication of scientific activities such as the Permen PAN and Bureaucratic Reform Number 16 of 2009. Forms of scientific publications can come from action research and experiments. The knowledge of elementary teachers about the methodology of action research and experimental research and the writing of scientific articles in journals that are still minimal is a problem for the teacher. Community Service is working with teacher groups in the sub-district of Genuk, Semarang, Central Java Province. Implementation of community service, in the form of training activities, workshops, research assistance and compiling journal articles. Journal articles from service participants who have fulfilled the requirements will have the opportunity to be published in the PGSD UNISSULA basic education journal. The implementation of service is done with teacher group partners in Genuk sub-district, but in the implementation the service team is advised to directly go to elementary school in Genuk UPTD, so the team the service chose 2 elementary schools in the Genuk UPTD namely SD Gebangsari 03 and SD Genuksari 02. Participants consisted of 50 elementary school teachers. The level of enthusiasm in participating in service activities is very high. The material provided during the training included classroom action research (CAR), experimental research, techniques for submitting journal articles through OJS. The service activities lasted for 2 months in each elementary school, namely the implementation of SD Gebangsari 03 in July to August 2018 while at SD Genuksari 02 held in September to October 2018 starting from observation to the service location, identifying problems up to training and mentoring making research and journal article. From the service activities that have been carried out there is hope from the partners to follow up this activity with PTS training activities or school action research for school principals.

Keywords: Action research, journal articles, SD teacher groups, mentoring research methodology

\section{PENDAHULUAN}

Berdasarkan informasi yang diperoleh pada Dapodik diperoleh data jumlah guru SD di Kecamatan Genuk berjumlah 321 guru. Adapun mayoritas pangkat guru SD masih pada golongan IIIA-IIIB. Berdasarkan wawancara kepada sebagian Kepala Sekolah di SD wilayah UPTD Genuk ternyata guru mengalami permasalahan dalam mengurus kenaikan pangkat. Hanya 30\% guru yang bisa menyelesaiakan kenaikan pangkat dan golongan mereka dengan baik. Sebagaimana yang disampaikan Zahera, Sy (1997) bahwa banyaknya guru-guru yang masih memiliki pangkat/golongan II/c maupun II/d, dan walaupun guru-guru tersebut sudah berupaya untuk menyelesaikan pendidikan S1, tapi masih mengalami kendala dalam kenaikan pangkat/jabatan yang disebabkan tidak terpenuhinya persyaratan sub unsur pengembangan profesi, dalam hal ini membuat karya tulis/karya ilmiah. Artinya masih banyak guru yang belum menyelesaikan atau bahkan tidak mengurus kenaikan pangkat dan golongan mereka 
dikarenakan belum terpenuhinya syarat publikasi ilmiah. Hal ini disebabkan belum tebiasanya guru melakukan penelitian.

Berdasarkan Permen PAN dan Reformasi Birokrasi Nomor 16 Tahun 2009 yang mengatur Jabatan Fungsional Guru dan Angka Kreditnya menjadi batu sandungan bagi guru. Selain dari unsur utama dari kegiatan mengajar, guru juga harus memenuhi unsur pengembangan profesi melalui publikasi kegiatan ilmiah atau karya inovatif. Seperti yang diketahui, Penerapan peraturan kenaikan pangkat guru tersebut di atas mulai berlaku periode Oktober 2013. Guru yang akan naik pangkat harus mengumpulkan angka kredit dari publikasi ilmiah atau karya inovatif sebagai berikut: Untuk naik pangkat dari III/b ke III/c 4 poin, III/c dke III/d 6 poin, III/d ke IV/a sebanyak 8 poin. Sementara itu, guru yang naik pangkat dari IV/a ke IV/b harus mengumpulkan angka kredit 10 poin. Dengan adanya peraturan tentang kenaikan pangkat dan jabatan guru yang baru di atas, memugkinkan akan menimbulkan masalah baru. Pangkat guru bisa tertahan pada golongan tertentu akibat tidak terpenuhinya persyaratan untuk naik pangkat setingkat di atasnya sehingga akan berdampak pada menurunnya kinerja para guru. Berbeda dengan aturan beberapa tahun sebelumnya yang mana Guru bisa naik pangkat minimal 2 tahun sekali setelah memenuhi angka kredit jabatan guru yang dipersyaratkan. Guru yang memiliki dedikasi dan kreativitas yang tinggi akan mampu mencapai jenjang kepangkatan maksimal bahkan bukan mustahil guru akan meraih jenjang kepangkatan IV/b atau IV/c menjelang masa pensiun.

Menulis karya ilmiah merupakan masalah yang umum dihadapi guru. Di samping keterbatasan kemampuan juga disebabkan oleh keterbatasan waktu. Guru sertifikasi wajib mengajar selama 24 jam perminggu. Sementara, membuat karya tulis hasil penelitian, semisal Penelitian Tindakan Kelas (PTK) butuh waktu yang cukup. Konsekuensi persyaratan kenaikan pangkat guru seperti di atas memungkinkan pangkat guru mentok pada golongan tertentu karena tidak sanggup memenuhi angka kredit poin publikasi karya ilmiah sehingga akan membuat kinerja guru menurun karena merasa tidak mungkin lagi untuk berkarir. Menurut Indrawati, H. (2013) dengan melakukan PTK guru memperoleh banyak manfaat diantaranya guru memiliki kemampuan memperbaiki proses pembelajaran melalui suatu kajian yang mendalam terhadap apa yang terjadi di kelasnya, guru dapat berkembang dan meningkatkankinerjanya secara profesional, karena guru mampu menilai, merefleksi diri, dan mampu memperbaiki pembelajaran yang dikelolanya, guru juga sebagai peneliti dibidangnya yang selalu inginmelakukan perbaikan-perbaikan pembelajaran yang inovatif dan kreatif.

Dampak yang tidak diinginkan lagi adalah guru "nekat" menggunakan jasa penulis untuk menulis karya tulis ilmiah. Padahal karya tulis ilmiah itu adalah pertanggungjawaban 
tertulis dari kegiatan ilmiah yang dilakukan oleh guru berkaitan dengan tugas mengajar di ruang kelas. Fenomena yang demikian juga dialami oleh guru SD di lingkungan UPTD Kecamatan Genuk. Rendahnya karya tulis ilmiah atau penelitian yang dilakukan oleh guru tentunya dengan beberapa alasan. Selain karena waktu dan tuntutan administrasi guru SD sebagai guru kelas sangat banyak, ternyata alasan lain yang cukup penting adalah kurangnya pemahaman guru terkait dengan metodologi penelitian. Baik penelitian tindakan kelas maupun penelitian eksperimen. Di samping itu, publikasi hasil penelitian yang dilakukan guru berupa artikel jurnal banyak yang tidak sesuai dengan review dari reviewer jurnal yang ingin di-submit. Hal ini karena tidak adanya pendampingan dari orang yang lebih faham akan metodologi penelitian, belum adanya pendampingan kepada guru dalam merevisi artikel sesuai dengan hasil review. Selain itu, masih kurangnya informasi tentang jurnal-jurnal yang relevan dengan artikel yang dibuat oleh guru.

Dengan demikian, jika fenomena ini tidak diatasi maka kenaikan pangkat guru tidak bisa diproses sehingga kinerja guru menurun dan ini akan memperngaruhi dari pada tujuan pendidikan nasional yang harus dicapai. Menurut Ridwan, A. (2017) kesulitan guru membuat proposal PTK dapat dipecahkan dengan pengadaan workshop dan diskusi dengan dibantun pembicara sebagai fasilitator di kalangan Guru. Oleh karena itu, diperlukan pengabdian masyarakat yang dapat peningkatkan pengetahuan guru tentang penelitian dan publikasi ilmiah melalui serangkaian kegiatan workshop dan pelatihan.

Adapun permasalahan pada kelompok Guru SD adalah meliputi, 1) Bagaimana meningkatkan pemahaman guru tentang metodologi penelitian pendidikan? 2) Bagaimana meningkatkan pemahaman guru dalam menyusun penelitian action research? 3) Bagaimana meningkatkan pemahaman guru dalam menyusun penelitian experiment? dan 4) Bagaimana Guru SD dapat mempublikasian hasil penelitian melalui penyusunan artikel jurnal?

Untuk mengembangkan kompetensi profesional para guru, maka solusi yang ditawarkan dalam kegiatan pengabdian masyarakat ini meliputi 1) Mengadakan pelatihan metodologi penelitian pendidikan pada guru SD di kecamatan Genuk Kota Semarang, 2) Mengadakan kegiatan workshop metodologi penelitian action research pada guru SD, 3) Mengadakan kegiatan pendampingan pada kegiatan penelitian eksperimen yang dilakukan oleh guru SD di kecamatan Genuk kota Semarang, dan 4) Mengadakan pendampingan dalam penyusunan artikel jurnal hasil penelitian yang dilakukan oleh guru SD di kecamatan Genuk kota Semarang.

Peningkatan pemahaman metodologi penelitian pendidikan bagi guru akan semakin berkembang dengan terlaksananya solusi yang diberikan dan pengelolaan manajemen usaha 
baik proses, penguasaan materi, pengelolaan SDM yang efektif sehingga mampu menghasilkan produk. Kegiatan pendampingan dilakukan sampai guru mampu menyusun publikasi ilmiah dan sebagai motivasi akan diterbitkan pada jurnal pendidikan dasar PGSD UNISSULA. Adapun target luaran pada kegiatan pengabdian masyarakat ini adalah publikasi ilmiah di Jurnal dan Prosiding. Serta publikasi artikel pada media massa cetak dan elektronik.

\section{METODE}

Pemecahan permasalahan pendampingan kelompok guru SD dalam meningkatkan pemahaman metodologi penelitian dilakukan dengan beberapa pendekatan yang dilakukan secara bersamasama, yaitu: 1) Ceramah dan tutorial, metode ini dilakukan pada kegiatan pelatihan dan workshop. Tim pelaksana pengabdian memberikan materi dengan metode ceramah disertai dengan tanya jawab serta tutorial untuk membantu peserta pengabdian. 2) Berbasis small group discussion, yaitu metode small group discussion adalah suatu cara mengajar yang dibagi menjadi beberapa kelompok. Setiap kelompok dibagi menjadi tiga sampai dengan lima orang (Fatimah, S., dkk., 2012). Mereka bekerja sama dalam memecahkan masalah atau menyelesaikan tugas, setelah diadakan pelatihan dan workshop. Maka ada kegiatan semacam diskusi kecil sebagai follow up dari pelatihan sebelumnya. Dalam small group discussion ini guru dibagi menjadi kelompok kecil untuk mendampingi penyusunan penelitian. 3) Komprehensif, seluruh kegiatan pengabdian masyarakat dilakukan secara serentak terkait dengan Sumber Daya manusia (SDM), proses belajar, publikasi melalui pelatihan dan pendampingan tenaga pengajar yang professional, 4) Learning by doing berbasis output. Hasil penelitian yang dilakukan dengan proses pendampingan diharuskan membuat publikasi untuk submit jurnal. Selanjutnya, ketiga metode di atas diimplementasikan dalam empat tahapan, yaitu sosialisasi, peningkatan kompetensi, produksi atau pelaksanaan kegiatan, serta monitoring dan evaluasi.

Pelaksanaan kegiatan pengabdian dilakukan dalam beberapa tahap dimulai pada bulan Juli sampai dengan Oktober 2018. Mitra yang direncakan adalah KKG UPTD kecamatan Genuk. Namun, pada prosesnya ada beberapa hal yang dipertimbangakan sehingga kami tidak dapat menggandeng KKG, namun disarankan langsung memilih 2 SD di lingkungan UPTD Genuk. Sehingga kami memilih SDN Genuksari 02 dan SDN Gebangsari 03. Pelaksanaan di masing-masing SD pada hari dan jam yang berbeda. Pelaksanaan di SDN Gebangsari pada bulan Juli sampai Agustus 2018, sedangkan di SDN Genuksari 02 dilaksanakan dalam Bulan 
September sampai Oktober 2018. Adapun tahap-tahap yang kami lakukan pada pengabdian ini meliputi:

\section{a. Sosialisasi Kegiatan PKM}

Pada tahap awal kegiatan pengabdian kami melakukan observasi awal sebagai bahan pengabdian kami. Selain observasi kami melakukan wawancara dan audensi kepada Kepala Sekolah dan Guru. Dari hasil observasi yang kami lakukan diperoleh data bahwa Guru di kedua Sekolah yaitu SDN Genuksari 02 dan SDN Gebangsari 03 masih memiliki motivasi dalam membuat karya tulis ilmiah yang masih rendah. Jika di SDN Gebangsari sudah ada guru yang membuat karya tulis ilmiah untuk keperluan kenaikan pangkat namun melihat prosesnya yang sangat ribet menjadikan guru tersebut berpikir dua kali untuk membuatnya lagi. Adapun di SDN Genuksari 02 ada guru yang sudah membuat karya ilmiah, namun memerlukan jurnal atau media publikasi yang dapat digunakan untuk submit artikelnya.

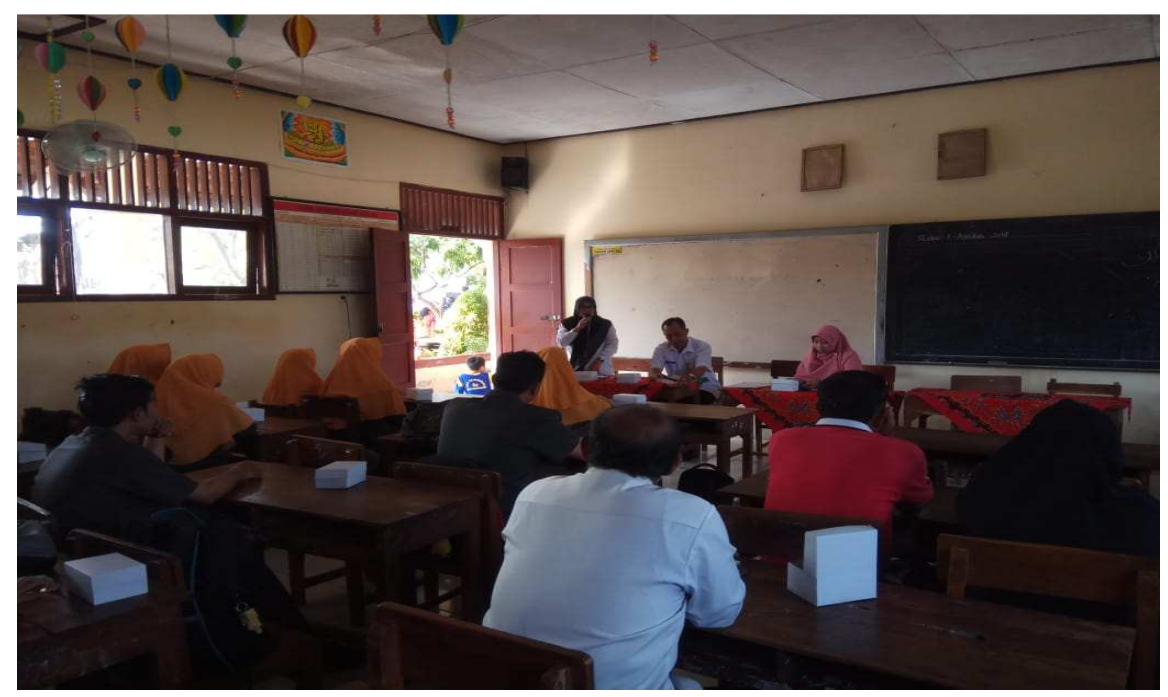

Gambar 1. Sosialisasi Pelaksanaan Pengabdian Masayarakat.

Dari berbagai alasan di atas maka Tim Pengabdian menjadikan hal tersebut sebagai latar belakang sehingga kami melakukan pengabdian terkait hal tersebut. Apa yang kami rencanakan kami sampaikan kepada Kepala Sekolah di SDN Gebangsari 03, yaitu Ibu Susilowati dan Kepala Sekolah SDN Genuksari 02, Bapak Suratna. Kami mensosialisasikan kegiatan pengabdian yang akan dilakukan di kedua SD tersebut. Kedua Sekolah tersebut sangat antusias dan tertarik pada kegiatan pengabdian yang akan kami lakukan. Kegiatan sosialisasi menjadi hal yang penting karena manfaat sosialisasi sebagai alat komunikasi untuk semua hal yang 
berhubungan dengan aktivitas dan yang hasilnya dapat dimanfaatkan untuk semakin memahamkan (Zees, R. F.,2012).

Pada tahap sosialisasi ini kami juga mendiskusikan kepada kepala sekolah tentang waktu pelaksanaan pengabdian yang tepat sehingga tidak mengganggu dalam proses kegiatan belajar mengajar. Selain itu, pada tahap ini kami juga melakukan wawancara kepada beberapa guru terkait perencanaan kegiatan pengabdian yang akan dilaksanakan, sehingga kami peroleh saran dan masukan dari berbagai pihak. Kegiatan pengabdian ini diharapkan dapat mengakomodir aspirasi dari berbagai pihak.

\section{b. Workshop Penelitian Tindakan Kelas (PTK) atau Action Research}

Berdasarkan permasalah yang kami temui maka pengabdian kami lakukan dengan beberapa kegiatan, salah satunya adalah workshop Penelitian Tindakan Kelas. Penelitian Tindakan Kelas merupakan penelitian yang sangat mudah untuk dilakukan guru. Menurut Ilfiandra, I., dkk (2016) PTK hakikatnya merupakan kegiatan ilmiah yang mampu merefleksikan kegiatan pembelajaran guru yang bersangkutan melalui prosedur ilmiah dan dapat dipertanggungjawabkan dengan prosedur dan persyaratan yang bisa dilakukan seorang guru tanpa mengurangi perhatiannya pada kelas dan prestasi siswa. Kegiatan penataran dan lokakarya mengenai PTK perlu dirancang dalam upaya meningkatkan kemampuan guru dan secara langsung mampu melakukan kegiatan penelitian. Karena guru setiap hari mengajar di kelas akan menemui banyak permasalahan yang terjadi di kelas. Sehingga dari permasalahan-permasalahan tersebut hendaknya menjadi pemikiran guru untuk bagaimana segera dipecahkan. Tentunya cara memecahkan masalah tersebut tidak serta merta begitu saja, namun perlu data dan pengujian lebih lanjut. Sampai pada akhirnya solusi permasalahan tersebut dapat menyelesaikan dengan tepat. Rendahnya pemahaman guru tentang hal ini dan sistematika penelitian tindakan kelas menjadi inisiatif kami untuk mengadakan workshop action research atau workshop penelitian tidakan kelas. Manurut Widayati, A. (2008) Penelitian Tindakan Kelas adalah suatu kegiatan penelitian yang berkonteks kelas yang dilaksanakan untuk memecahkan masalah-masalah pembelajaran yang dihadapi oleh guru, memperbaiki mutu dan hasil pembelajaran dan mencobakan hal-hal baru dalam pembelajaran demi peningkatan mutu dan hasil pembelajaran.

Pelaksanaan workshop di lokasi pengabdian dilakukan pada hari yang berbeda. Di SDN Gebangasari 03 dilakukan pada tanggal 21 Agustus 2018. Adapun di SDN Genuksari 02 dilaksanakan pada tanggal 8 Oktober 2018. Dalam pelaksanan workshop ini diikuti sekitar 50 Peserta. Penyampaian materi pada workshop Penelitian Tindakan Kelas disampaikan oleh tiga Narasumber, yaitu Yulina Ismiyanti, M.Pd yang memberikan materi tentang "Guru sebagai 
Indonesian Journal of Community Services

E-ISSN: 2684-8619

Volume 1, No. 1, May 2019

http://jurnal.unissula.ac.id/index.php/ijocs DOI: http://dx.doi.org/10.30659/ijocs.1.1.32-47

Peneliti melalui Penelitian Tindakan Kelas". Materi juga disampaikan Nuhyal Ulia, M.Pd tentang "Metodologi Penelitian Tindakan Kelas" dan Rida Fironika, M.Pd juga menyampaikan media pembelajaran yang dapat dijadikan sebagai bahan untuk penelitian Tindakan Kelas. Untuk lebih jelasnya dapat dilihat pada gambar berikut.

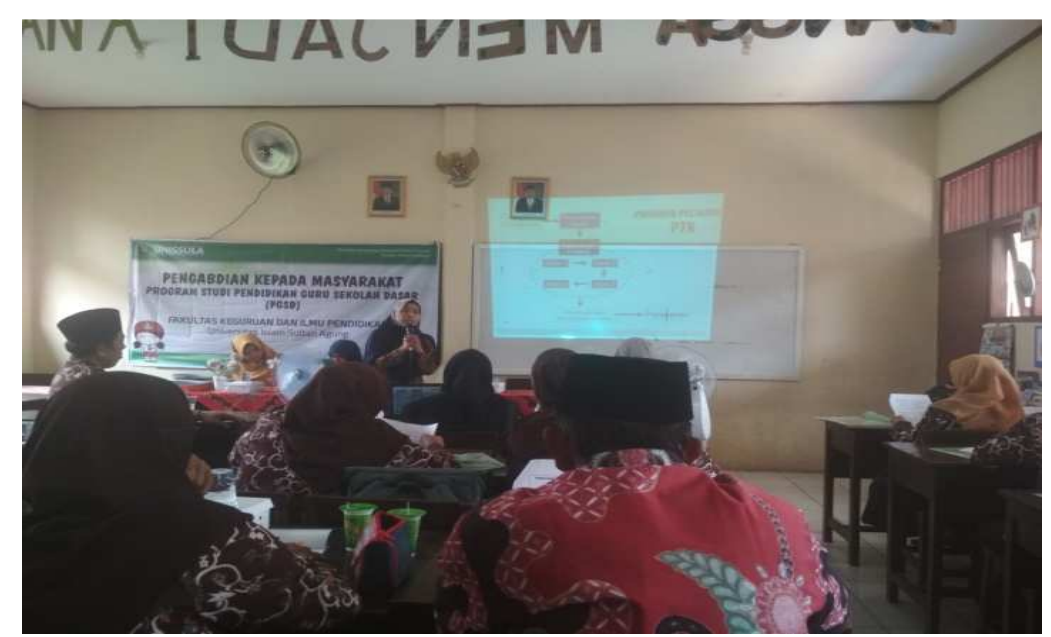

Gambar 2. Pemberian materi Action Research.

Materi yang disampaikan oleh Ibu Yulina Ismiyanti, M.Pd adalah tentang pengertian dan prosedur pelaksanaan PTK. Dalam hal ini juga disampaikan motivasi kepada guru akan pentingnya dan mudahnya melakukan Penelitian Tindakan Kelas. Guru dalam mengajar tentunya mendapati berbagai masalah dalam kelas. Masalah yang ditemukan tersebut hendaknya dicari solusinya. Maka solusi yang ditemukan oleh guru alangkah lebih baik jika diuji kelayakannya melalui Penelitian Tindakan Kelas. Saat penyampaian materi ini, guru sangat antusias dan memperhatikan sehingga pada saat tanya jawab ada banyak pertanyaan yang dilontarkan pada penyaji Tim Pengabdian Masyarakat. 


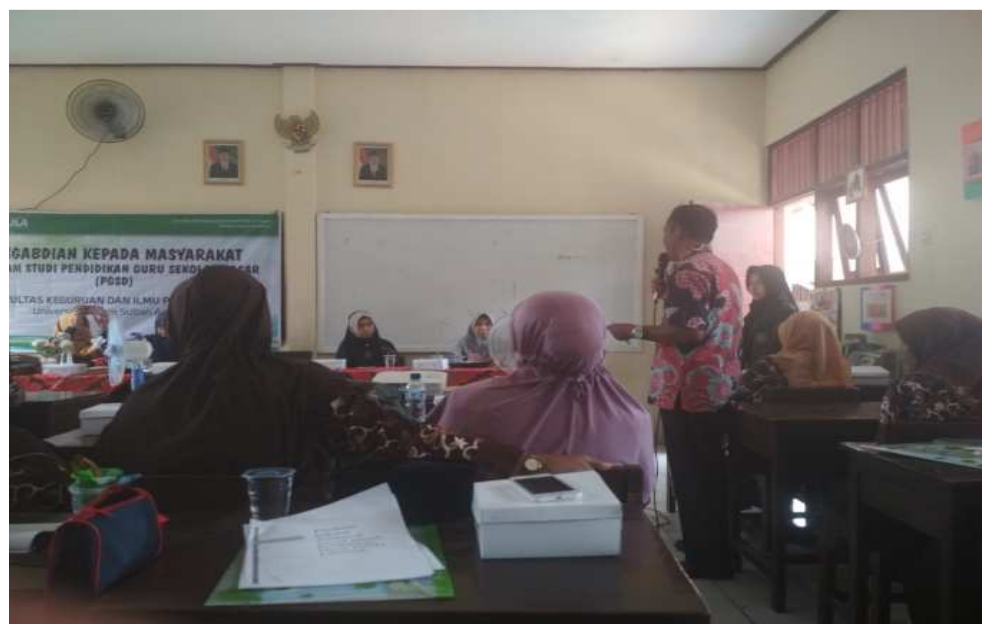

Gambar 3. Peserta Workshop Action Research aktif mengajukan pertanyaan.

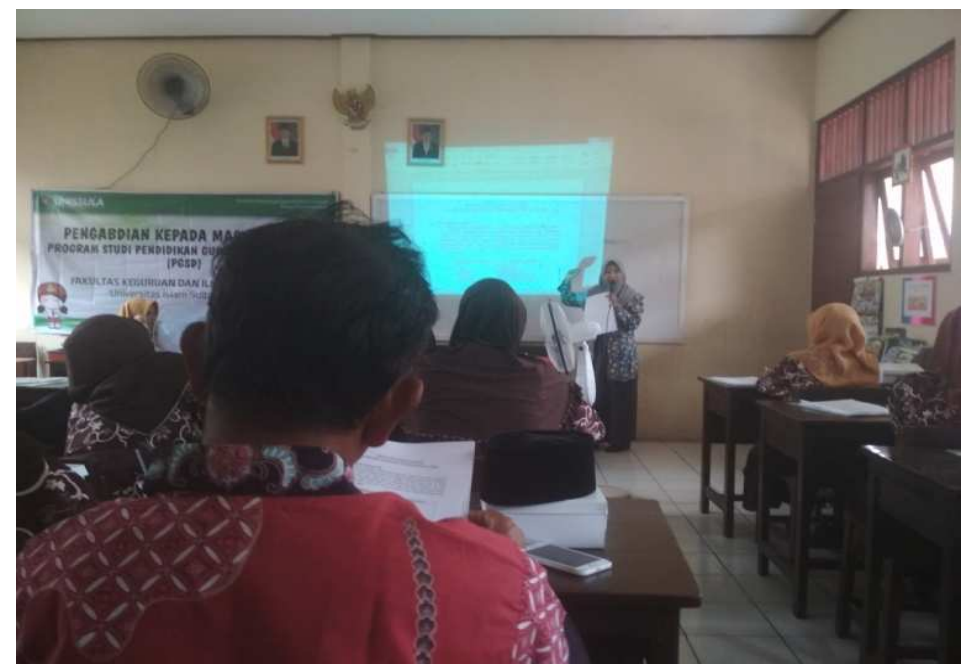

Gambar 4. Pemberian Materi Metodologi PTK.

Penyajian materi selanjutnnya adalah metodologi atau sistematika dalam Penelitian Tindakan Kelas meliputi bagaimana model PTK yang dikembangkan. Teknik pengumpulan data, instrumen penelitian sampai di teknik analisis data pada Penelitian Tindakan Kelas. Materi ini disampaikan oleh Nuhyal Ulia, M.Pd. Dalam penyusunan Bab III pada penelitian PTK memang agak sulit karena memiliki teknik sendiri yang harus dipahami oleh peneliti. Penyusunan instrumen juga harus sesuai dengan tujuan penelitian yang diinginkan. Dalam menganalisis peneliti harus memahami statistik deskriptif sehingga akan mengolah data dengan baik dan mampu memahami arti dari data yang diperoleh. Sehingga dapat menyimpulkan hasil penelitian tindakan kelas. 
Pada saat workshop berlangsung kami juga menyampaikan materi tentang media pembelajaran. Diharapkan dapat menjadi alternatif dalam mencari bahan atau solusi pada penelitian tindakan kelas. Guru masih belum menggunakan media secara maksimal dalam pembelajaran. Hal ini dikarenakan sulitnya atau masih kurangnya pengetahuan guru dalam membuat media pembelajaran. Padahal media yang dibuat dapat memanfaatkan barang-barang di sekitar lingkungan sendiri dan mudah untuk diperoleh. Dengan alasan inilah kami memberikan materi bagaimana pembuatan media pembelajaran dengan mudah dan dapat mencapai tujuan pembelajaran. Materi ini disampaiakan oleh Rida Fironika, M.Pd.
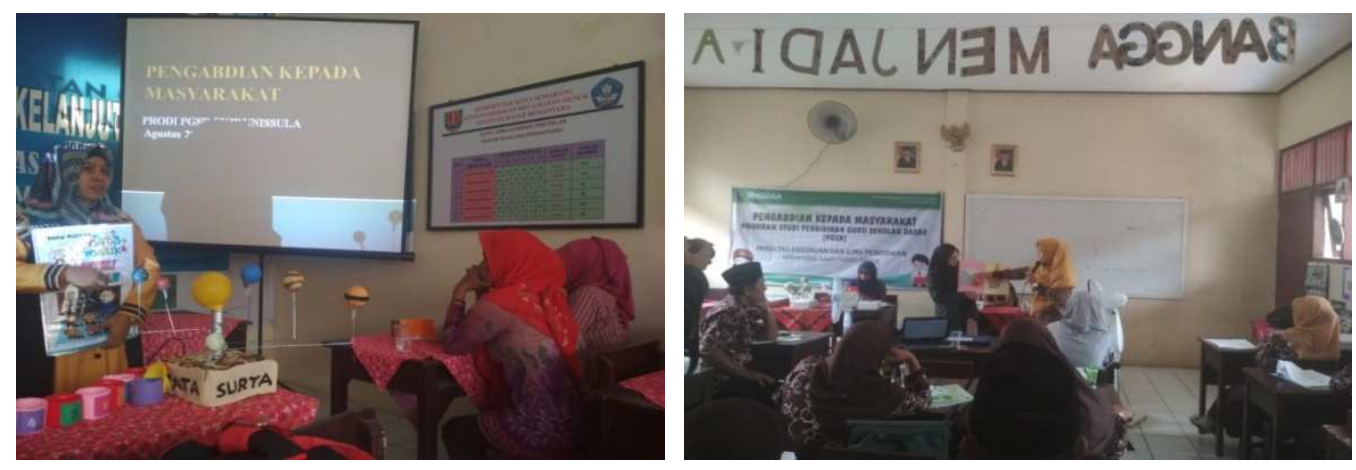

Gambar 5. Pemberian Materi Media Pembelajaran.

\section{c. Pelatihan Metodologi Penelitian Eksperimen}

Pada pengabdian masyarakat ini disampaikan tidak hanya tentang Penelitian Tindakan Kelas (PTK), namun juga tentang jenis penelitian yang lainnya, yaitu disampaikan tentang penelitian eksperimen. Dipilih penelitian eksperimen yang merupakan penelitian kuantitaif dikarenakan sebagai alternatif jenis penelitian yang sekiranya dapat dilakukan oleh guru. Karena pada jenis penelitian ini hampir sama dengan Penelitian Tindakan Kelas (PTK) dalam hal treatmen yang dilakukan. Perbedaan terdapat pada metodologi dan analisis data yang digunakan. Guru tidak banyak memilih jenis penelitian ini karena masih kurang pengetahuan yang mereka miliki. Alasan inilah yang melatarbelakangi tim pengabdian memberikan pelatihan metodologi penelitian eksperimen. Pada pelatihan ini disampaiakan oleh Nuhyal Ulia, M.Pd dan Erna Noviyanti, M.Pd. 


\section{Indonesian Journal of Community Services \\ E-ISSN: 2684-8619}

Volume 1, No. 1, May 2019

http://jurnal.unissula.ac.id/index.php/ijocs DOI: http://dx.doi.org/10.30659/ijocs.1.1.32-47

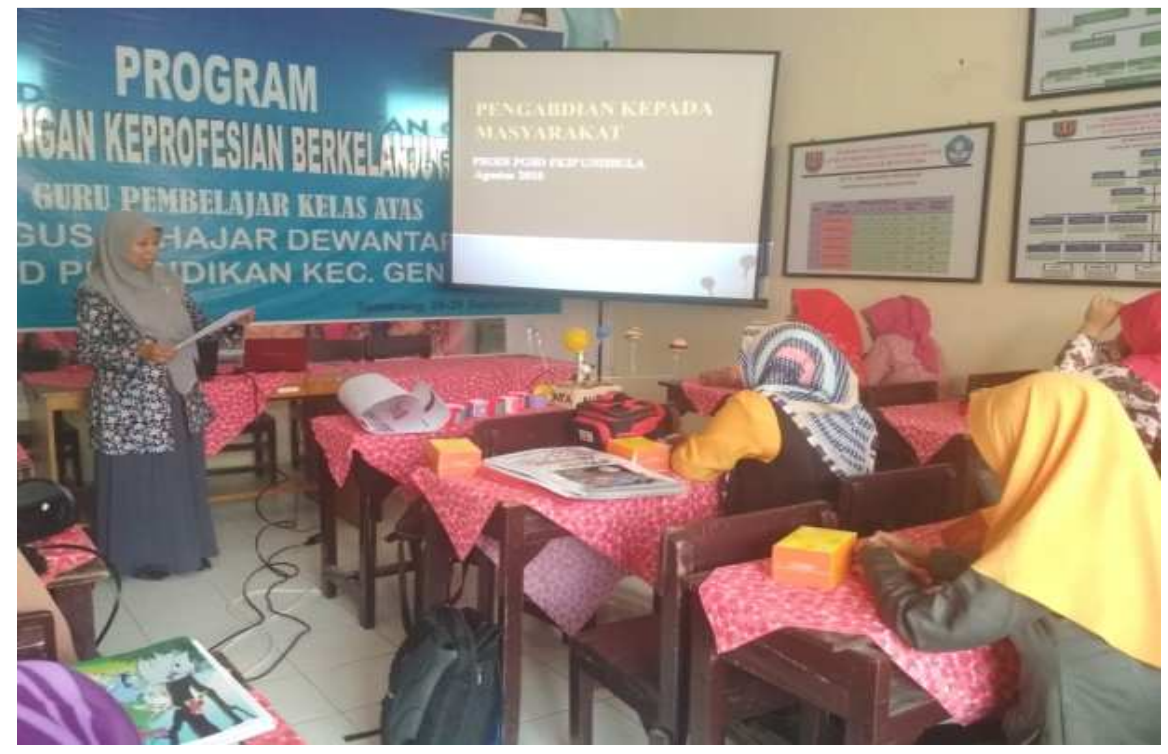

Gambar 6. Pemberian materi Metodologi Penelitian Eksperimen.

Publikasi ilmiah yang diwajibkan kepada guru tidak hanya tentang artikel hasil penelitian tindakan kelas, namun juga dapat tentang jenis penelitian lainnya, seperti penelitian kuantitatif atau penelitian kualitatif. Pelatihan metodologi penelitian eksperimen dilaksanakan di SDN Gebangsari 03 dan SDN Genuksari 02. Guru sangat antusias saat pelatihan berlangsung. Pelatihan ini diharapkan mampu memberikan pengetahuan kepada guru akan alternatif jenis penelitian pendidikan selain penelitian tindakan kelas (PTK).

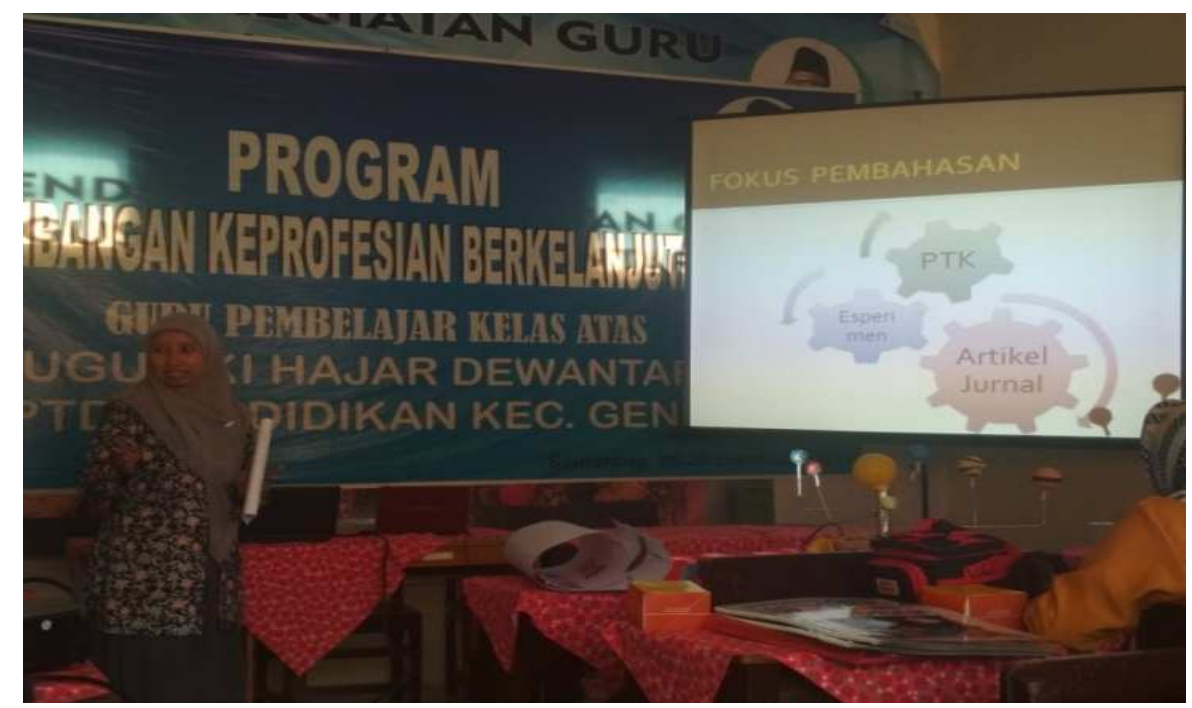

Gambar 7. Pemberian materi Metodologi Penelitian Eksperimen. 
Pada pelatihan metodologi penelitian eksperimen juga disampaikan materi tentang bagaimana treatment yang baik yang dapat digunakan oleh guru. Di antaranya dengan membuat bahan ajar yang menarik bagi siswa. Bahan ajar dapat berupa buku cerita, atau komik.

\section{d. Pelaksanaan Kegiatan Pendampingan Penulisan Artikel Jurnal}

Pada rangkaian kegiatan pengabdian yang diadakan adalah dalam rangka memacu motivasi guru dalam membuat karya tulis untuk dipublikasikan baik secara online maupun offline. Guru masih mempunyai akses yang minim untuk mempublikasikan karyanya melalui online. Padahal publikasi ilmiah menjadi syarat wajib yang harus dipenuhi dalam rangka kenaikan pangkat. Dengan demikian, dari rangkaian kegiatan pengabdian kami mengadakan pendampingan penulisan artikel jurnal. Namun sebelum pendampingan dilaksanakan, kami memberikan materi tentang bagaimana teknik men-submit artikel ilmiah pada jurnal melalui sistem OJS atau Open Journal System yang belum familier di kalangan guru. Berdasarkan wawancara sebelumnya guru hanya menitipkan kepada pengelola jurnal melalui email dan menyerahkan editing kepada pengelola sampai artikel tersebut terbit. Padahal, guru bisa melakukan submit sendiri tidak harus melalui pengelola jurnal. Oleh karena itu, kami menyampaikan langkah-langkah men-submit artikel melalui OJS sehingga guru dapat men-submit sendiri. Materi ini disampaikan oleh Ibu Sari Yustiana, M.Pd beliau menyampaikan dengan detil dan jelas dan melakukan simulasi langsung cara men-submit. Adapun jurnal yang kami rekomendasikan adalah Jurnal Pendidikan Dasar yang diterbitkan oleh Prodi PGSD UNISSULA. Dengan demikian, diharapkan guru yang sudah siap submit ke sistem jurnal kami, dapat melakukan dengan mudah dan sesuai dengan output yang diharapkan akan adanya artikel pada jurnal kami berasal dari Guru SD Mitra PGSD UNISSULA. 


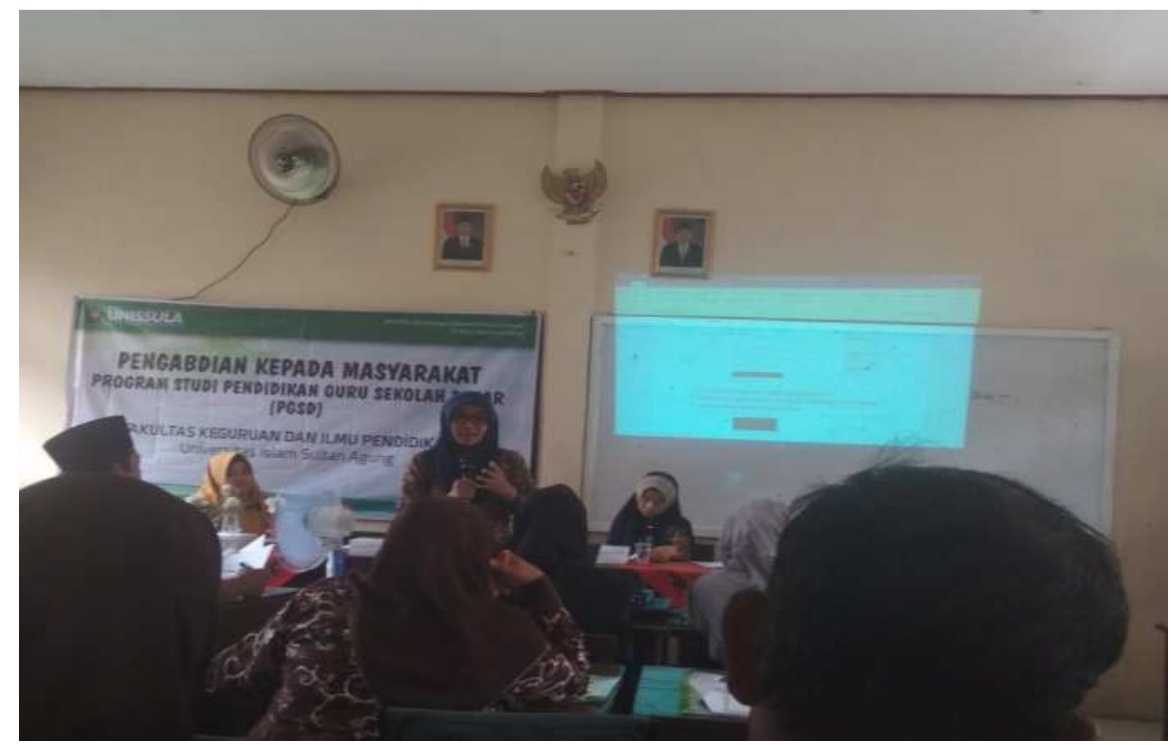

Gambar 8. Pemberian materi tentang Artikel Jurnal.

\section{e. Monitoring dan Evaluasi}

Tahapan akhir dari rangkaian kegiatan pengabdian masyarakat yang dilakukan adalah monitoring dan evaluasi. Selama kegiatan pengabdian masyarakat berlangsung dengan baik di SDN Gebangsai 03 dan SDN Genuksari 02, berjalan dengan lancar dan memperoleh respon yang baik dari kepala sekolah maupun dewan guru. Kegiatan monitoring yang kami lakukan adalah monitoring saat berlangsungnya kegiatan sosialisai, workshop, dan pelatihan. Hasil monitoring yang dilakukan terlihat setiap kegiatan berjalan sesuai dengan rencana. Estimasi dana dan waktu tidak banyak berubah. Materi yang disajikan tidak ada yang tertinggal. Pelaksanaan sesuai dengan tanggal yang telah disepakati pihak sekolah dan tim pengabdian masyarakat. Pelaksanaan monitoring juga kami lakukan terhadap pendampingan pembuatan artikel jurnal oleh guru. Kami sudah menyampaikan kepada semua guru akan siap sedia, baik langsung maupun tidak untuk melaksanakan monitoring dan pendampingan jika ada guru yang berkenan. Hal ini memperoleh tanggapan yang baik dari guru dan kepala sekolah. Pendampingan yang kami lakukan sampai dengan artikel ilmiah yang dibuat guru terbit secara online maupun cetak.

Adapun evaluasi kami lakukan secara terus-menerus dan berkesinambungan. Selama pelaksanaan kegiatan baik sosialisasi, workshop, maupun pelatihan di SDN Gebangsari 03 dan SDN Genuksari 02 banyak saran dan kritik yang kami dapat. Di antaranya waktu yang diadakan masih kurang apalagi saat pelatihan acara dimulai terlambat sehingga waktu berkurang. Selain itu, ada beberapa guru yang tidak dapat hadir karena sedang tugas luar, yakni pelatihan di luar sekolah sehingga tidak bisa semua guru dapat mengikutinya, padahal kegiatan ini dirasa 
penting. Bagi kepala sekolah mungkin PTK tidak berarti karena kepala sekolah dituntut untuk membuat PTS (Penelitian Tindakan Sekolah). Oleh karena itu, masukan dari Kepala Sekolah untuk mengadakan pengabdian lagi di lain waktu tentang Penelitian Tindakan Sekolah bagi kepala sekolah melalui KKS, yaitu Kelompok Kepala Sekolah.

\section{HASIL DAN PEMBAHASAN}

Dengan adanya pelaksnaan pengabdian kepada masyarakat di Sekolah di lingkungan UPT kecamatan Genuk kota Semarang dapat memberikan banyak manfaat kepada Guru, baik di SDN Gebangsari 03 maupun di SDN Genuksari 02. Metodologi penelitian sebelumnya hanya dipandang sebagai mata kuliah saja. Namun, ternyata sangat mereka perlukan dalam menyusun karya tulis ilmiah tentang hasil penelitian. Sistematika dalam menyusun proposal dan laporan penelitian menjadi hal yang penting. Apalagi untuk kepentingan pengajuan kenaikan pangkat dan golongan. Oleh karena itu, dengan adanya pelatihan tentang metodologi penelitian pendidikan menjadikan guru semakin memahami sistematika dalam menyusun sebuah penelitian. Guru mendapatkan pengetahuan dan informasi tentang sistematika atau metodologi penelitian yang benar. Selain itu, kegiatan ini akan membuta guru mengingat kembali pengetahuan yang sebenarnya sudah mereka peroleh ketika masih di bangku perkuliahan. Apalagi jika ada guru yang sedang menempuh studi lanjut pascasarjana, hal ini menjadi lebih hidup karena dapat menjadi ajang diskusi dan Tanya jawab terkait metodologi penelitian. Sebagai contoh di SDN Genuksari 02 salah satu guru yang bernama Bapak Masykuri yang kebetulan sedang menempuh pendidikan S2 menanyakan tentang perbedaan sistematika penelitian eksperimen dan penelitian pengembangan.

Penelitian Action Research (PTK) menjadi hal yang sangat dibutuhkan oleh setiap guru terutama guru di lingkungan PNS yang hendak melaksanakan kenaikan pangkat dan golongan. Saat kegiatan pengabdian berlangsung, kami mencoba melakukan tanya jawab kepada peserta. Apakah sudah pernah menyusun PTK? Sebagian ada yang menjawab belum pernah sama sekali, ada beberapa yang menjawab sudah pernah membuat, namun belum maksimal. Dari jawaban tersebut dapat disimpulkan bahwa guru membuat PTK belum sesuai dengan sistematika PTK yang benar. Dengan demikian, adanya pelatihan tentang PTK jelas akan memberikan pegetahuan dan informasi kepada guru bagaimana langkah-langkah melakukan PTK dan bagaimana sistematika menyusun laporan PTK. Tim pengabdian juga melakukan pendampingan kepada guru terkait dalam penyusunan PTK. Kami open access kepada mereka dengan tujuan PTK yang telah dibuat oleh guru sesuai dengan sistematika yang seharusnya. Bagi guru yang 
belum pernah membuat Penelitian PTK, kegiatan ini sangat memotivasi mereka. Guru-guru sangat antusias terlihat saat pelaksanaan pelatihan banyak pertanyaan yang ditujukan kepada narasumber terkait Penelitian PTK.

Jenis penelitian tidak hanyaPenelitian PTK, namun ada penelitian kualitatif dan kuantitatif atau eksperimen. Fakta di lapangan, penelitian jenis ini jarang diminati di kalangan guru, bahkan tidak sama sekali. Padahal saat ditanya tentang penelitian kuantitatif, sudah pernah mereka kenal di bangku kuliah. Ada beberapa guru bahkan yang mengambil penelitian kuantitatif sebagai bahan penyusun skripsi. Penelitian kuantitatif jarang dipilih karena alasan pengolahan data yang membutuhkan pemikiran lebih dalam. Kurangnya pengetahuan tentang penelitian kuantitatif mungkin juga menjadi alasan bagu guru sehingga tidak memilih penelitian tersebut. Padahal pelaksanaan penelitian kuantitaif tidak membutuhkan waktu yang lama seperti Penelitian PTK yang memakan beberapa siklus. Tim pengabdian memberikan materi tentang penelitian eksperimen di lingkungan guru, agar para guru mendapat wawasan tentang penelitian eksperimen dan termotivasi dalam membuat penelitian eksperimen. Dengan demikian, akan mampu meingkatkan pemahaman guru tentang penelitian eksperimen.

Penelitian yang dilaksanakan oleh guru perlu dipublikasikan. Hal ini sesuai dengan aturan kenaikan pangkat dan golongan bahwa karya ilmiah tersebut harus dipublikasikan di jurnal yang ber-ISSN. Dengan demikian, guru perlu mengetahui sistematika membuat artikel hasil penelitian dan teknis dalam submit di sebuah jurnal ilmiah. Publikasi merupakan program puncak dari kegiatan pengabdian yang kami lakukan. Kami mendampingi dalam pelaksanaan penelitian sampai pada pembuatan artikel jurnal. Kami juga memberikan simulasi tentang teknik submit di jurnal PGSD UNISSULA.

\section{KESIMPULAN}

Pengetahuan Guru SD tentang metodologi penelitian PTK dan penelitian eksperimen serta penulisan artikel ilmiah pada jurnal yang masih minim menjadi masalah tersendiri bagi guru tersebut. Para guru membutuhkan pelatihan dan pendampingan tentang metodologi penelitian dan penulisan artikel jurnal. Dalam melaksanakan kegiatan pengabdian, akan diadakan pelatihan, workshop, pendampingan dalam melakukan penelitian dan pendampingan dalam menyusun artikel jurnal. Kegiatan pengabdian berlangsung kurang lebih selama dua bulan dimulai dari observasi ke lokasi pengabdian, identifikasi masalah sampai dengan pelatihan dan pendampingan pembuatan penelitian dan artikel jurnal. Dari kegiatan pengabdian yang sudah 
dilaksanakan ada harapan dari pihak mitra untuk menindaklanjuti kegiatan ini dengan kegiatan pelatihan PTS bagi kalangan kepala sekolah.

\section{UCAPAN TERIMA KASIH}

Tim pelaksana pengabdian mengucapkan terima kasih kepada guru SDN Gebangsari 03 maupun di SDN Genuksari 02 yang telah menjadi mitra dalam pelaksanaan pengabdian ini, Lembaga Penelitian dan Pengabdian Masyarakat (LPPM) UNISSULA Semarang, serta pihak terkait lain yang telah membantu selama kegiatan.

\section{DAFTAR PUSTAKA}

Fatimah, S., dkk. (2012). Pembelajaran fisika menggunakan model cooperative learning ditinjau dari prestasi belajar siswa. Jurnal Kependidikan: Penelitian Inovasi Pembelajaran, 42(1).Fatimah, S., Kartika, I., \& Niyartama, T. F. (2012). Pembelajaran fisika menggunakan model cooperative learning ditinjau dari prestasi belajar siswa. Jurnal Kependidikan: Penelitian Inovasi Pembelajaran, 42(1).

Ilfiandra, I., Suherman, U., Akhmad, S. N., Budiamin, A., \& Setiawati, S. (2016). Pelatihan dan Pendampingan Penulisan Karya Tulis Ilmiah Bagi Guru SD. Jurnal Pengabdian Pada Masyarakat, 1(1), 70-81.

Indrawati, H. (2013). Upaya Peningkatan Kompetensi Profesional Guru Mata Pelajaran Ekonomi dalam Proses Pembelajaran. Jurnal Pendidikan, 4(2), 84-95.

Kemendikbud. 2013. "Pendekatan \& Startegi pembelajaran”(Bahan Ajar Diklat Guru dalam Rangka Implementasi Kurikulum 2013). Jakarta: Kementrian Pendidikan dan Kebudayaan.

Kemendikbud. 2013. Permendikbud No. 64 tentang Standar Isi Pendidikan Dasar dan Menengah. Jakarta: Kementrian Pendidikan dan Kebudayaan.

Metode Tematik Integratif. http://www.sekolahdasar.net/2012/12/metode-tematik-integratifpada.html\#ixzz3tyL5KKFg diunduh 8 Desember 2015

Ridwan, A.(2017). Peningkatan Mutu Dikalangan Guru SD Gugus Diponegoro kecamatan Ungaran Barat Dengan Kemampuan Penyusunan Proposal PTK melalui Workshop. Jurnal Penjaminan Mutu, 3(1), 23-30.

Widayati, A. (2008). Penelitian tindakan kelas. Jurnal Pendidikan Akuntansi Indonesia, 6(1).

Zahera, Sy. (1997). Hubungan Konsep Diri dan Kepuasan Kerja dengan Sikap Guru dalam Proses Belajar-Mengajar. Jurnal Ilmu Pendidikan Universitas Negeri Malang, 4(3).

Zees, R. F. (2012). Analisis Faktor Budaya Organisasi Yang Berhubungan Dengan Perilaku Caring Perawat Pelaksana Di Ruang Rawat Inap RSUD. Prof. Dr. H. Aloei saboe Kota Gorontalo. Jurnal Health and Sport, 5(01). 